佐藤雅昭 1

\title{
Strategies for the Intraoperative Localization of Small Lung Cancer -Preoperative Marking Techniques and Virtual-assisted Lung Mapping-
}

\author{
Masaaki Sato1 \\ ${ }^{1}$ Department of Thoracic Surgery, Kyoto University Hospital, Japan.
}

ABSTRACT - Small lung tumors with ground glass opacity (GGO) are often not palpable during surgery. Therefore, identifying and localizing these lesions is a major challenge in the field of general thoracic surgery. To date, a number of strategies for detecting such lesions have been reported, although each has advantages and disadvantages. Intraoperative ultrasound and the Endofinger are non-invasive tools for isolating small lung tumors, although the accuracy of these devices for identifying GGO lesions is controversial. Reported preoperative lung marking techniques using percutaneous CT-guided needle puncture include the placement of a hook wire and injection of dye or Lipiodol ${ }^{\mathbb{R}}$. Although these techniques are relatively concise, the number of areas suitable for percutaneous needle puncture is anatomically limited, and there are concerns regarding complications, such as pneumothorax, apparatus dislodgement (especially the hook wire) and potentially fatal air embolism. Peribronchial marking techniques include the injection of dye, barium or Lipiodol. These strategies are considered to be relatively safe, although, if marking is conducted under CT guidance, the setup may be troublesome and excessive radiation exposure for the bronchoscopist is a problem. Recent advances in virtual bronchoscopy may overcome these limitations. We recently reported a novel strategy, termed virtual-assisted lung mapping (VAL-MAP), which is an extension of the bronchoscopic technique. In VAL-MAP, multiple markings are made on the lung surface by bronchoscopically injecting dye under fluoroscopy with the guidance of virtual bronchoscopy. These markings provide "geometric information" on the lung surface. Beyond the conventional concept of "lung marking", VAL-MAP is expected to play a role as an intraoperative navigation system in the field of general thoracic surgery by allowing the surgeon to set precise resection lines in patients undergoing lung wedge resection and/ or complex segmentectomy.

(JJLC. 2014;54:835-842)

KEY WORDS — Ground glass opacity (GGO), Marking, Video-assisted thoracic surgery (VATS), Complication, Virtual-assisted lung mapping (VAL-MAP)

要旨——Ground glass opacity $(\mathrm{GGO})$ 病変に代表される 触知困難小型病変の術中同定は, 呼吸器外科の大きな課 題である。これまで様々な方法が報告されてきたが一長 一短である。超音波や Endofinger は侵襲が皆無だが, GGO 病変をどれほど正確に同定できるか疑問が残る. CT ガイド下に経皮的に針を刺す術前マーキング法とし て hook wire 留置, 色素注入, リピオドール®注入などが 報告されている. 比較的簡便な一方, 穿刺可能部位が制 限されること, 気胸や器具脱落 (hook wire), 致命的とな
りうる空気塞栓の懸念がある．経気管支的なマーキング 法として, 色素, バリウム, リピオドールなどの注入が 報告されている，比較的安全な方法と思われるが， CT ガイド下に行うにはセッティングに手間がかかること, 術者被曝が多くなることなどが欠点である．最近のバー チャル気管支鏡の進歩はこれらの欠点を補う可能性があ る.われわれが最近報告した virtual-assisted lung mapping (VAL-MAP) 法はこの延長上にあるといえ，複数の 標的部位にバーチャル気管支鏡ガイド下に透視下, 気管

1京都大学医学部附属病院呼吸器外科. 
支鏡下に色素を注入し，肺表面に「地理情報」を与える． 病変同定というマーキングの概念を抜け出し, 肺部分切 除や複雑な区域切除で精密な切離ラインの設定を可能な らしめる, 呼吸器外科領域の術中ナビゲーションとして
の役割が期待される.

索引用語 — Ground glass opacity (GGO), マーキング, Video-assisted thoracic surgery (VATS), 合 併 症, Virtual-assisted lung mapping (VAL-MAP)

\section{背 景}

高解像度 CT の普及により, ますます多くの微小肺癌, またはその疑いのある病変が見つかるようになった。そ の多くは ground glass opacity（GGO）を呈するため, 手 術の現場では触診が困難である。さらに最近はほとんど の呼吸器外科手術が胸腔鏡下に行われるため, 小さな ポート孔を通じての触診はますます困難であり, 微小肺 病変の同定・切除という点ではまさに外科医泣かせの時 代となった.

こうした触知困難な小型肺癌に対する術中同定法とし て，これまで様々なものが考案，報告されてきた，術中 超音波や Endofinger による小型病変の術中同定は, 基本 的に新たな侵襲を伴わない方法であり良好な結果が報告 されているが, GGO 病変についてどの程度確実に病変を 探知できるか, またその簡便性については評価が一定し ない. 術前マーキング法として最も多く使われてきたの はおそらくCTガイド下の hook wire の留置と思われ る. ${ }^{1}$ しかしこの方法は肩甲骨裏面など部位の制限と, 高 頻度に認められる気胸・出血などの合併症 (30\% 程度), 術中の hook wire の喪失 $($ ～ $5 \%$ と報告される $), 2$ そして 致死的になりうる空気塞栓3-6のリスクが大きな問題で ある.一方, CT ガイド下気管支鏡マーキングの報告もあ り, 7 理論的には針を刺さないため空気塞栓の可能性は 低いと予想される。しかし CT 室を気管支鏡で長時間占 拠するロジスティックな問題点があり, 術者の被曝など も問題となる．本稿では，これまで報告された微小肺病 変同定法を紹介し，そのメリット，デメリットを議論す る（Table 1）とともに，最近われわれが報告し，2014 年 5 月現在, 既に全国で 200 例近くの症例に実施されて いる virtual-assisted lung mapping（VAL-MAP）法につ いて紹介する.

\section{1. 非侵襲的方法}

\section{1-1. 術中超音波}

胸腔鏡下に肺を虚脱させた状態で，胸腔鏡下手術でも 使用可能な超音波プローブを肺に押し当てることで，肺 内病変を探知する。まったく新たな侵襲を患者に加えず に施行可能である。また事前の準備も不要であり，装置 が施設にあれば，術者が必要と思った時点で使用するこ
とができるのは大きなメリットである，一方，手技は施 術者の技術に大きく依存すると思われる. 50 例前後を集 めたシリーズでは良好な成績が複数報告されている が, 8,9 再現性がどれほどあるのか未知数である.また, 報 告のほとんどは solid な腫瘍を対象としたものである. CTで GGO として認識される病変に関する報告は少な く,こうした病変での術中超音波の役割は未確定である.

\section{1-2. Endofinger}

触覚センサーを用いて対象物の硬さを感知するシステ ムで，胸腔鏡下手術において触診が困難である場合，文 字通り指の代わりに触診を可能にするために開発され た. 10 新たな侵襲を患者に加えずに施行可能であるもの の, 報告されている症例数は少なく, その確実性につい ては十分な検討がなされているとはいえない.また GGO 病変に関してはデータがなく，この方法は現在普及には 至っていない.

\section{CT ガイド下経皮穿刺法}

\section{2-1. CT ガイド hook wire 留置}

これまで最も広く用いられた小型肺癌の術中局在同定 方法の一つと思われる. まず術前に CT ガイド下, 経皮的 に hook wire を腫瘍近傍の肺に留置し，これにつながっ た糸を体外に残すことで，術中はこれを頼りに手術を行 う. 手技は比較的簡便であったが, hook wire の脱落, 遺 残が問題の一つであった。これを改善するために suturing system を取り达んだ機材が開発され, 11 ガイディン グマーカーシステム（八光）として販売されている. Dendo らは 146 人の患者に対する 168 回のマーキング の結果を報告した.1これによれば，無症状の気胸が $32.1 \%$ と比較的高頻度に観察され, 肺内出血が $14.9 \%$ に, 胸腔内への出血が $0.6 \%$ に認められたが, 深刻な合併 症はなかったと報告されている。，一方，全国的には合併 症は多く報告されており，添付文書にも有害事象として 気胸, 空気塞栓, 肺出血・肺内血腫, マーカーの遺残, 悪性細胞の播種, 臓器の挫滅が記載されている. 特に懸 念されるのが, 空気塞栓と続発する脳梗塞や心筋梗塞の 重篤な合併症である. ${ }^{4,5,12}$ 正確な発症頻度は不明だが, 1.5〜 2\%との報告がある. 6,12 発症のメカニズムとして は, 肺静脈の外気との交通, 気道と肺静脈の交通などの 機序が考えられ，後者では CT 時の息ごらえによる気道 
Intraoperative Localization of Small Lung Cancer-Sato

Table 1. Comparison of Techniques Used to Identify Small Lung Tumors During Surgery

\begin{tabular}{|c|c|c|c|}
\hline Name & Description & Advantages & Disadvantages \\
\hline \multicolumn{4}{|l|}{ Non-invasive methods } \\
\hline Ultrasound (US) & $\begin{array}{l}\text { Intraoperative US to detect tu- } \\
\text { mor in the collapsed lung }\end{array}$ & Non-invasive & $\begin{array}{l}\text { Uncertain sensitivity and specificity for } \\
\text { GGO lesions, heavily operator dependent }\end{array}$ \\
\hline Endofinger & $\begin{array}{l}\text { Use of tactile sensor during op- } \\
\text { eration }\end{array}$ & Non-invasive & $\begin{array}{l}\text { Limited data about sensitivity and speci- } \\
\text { ficity, almost no data regarding GGO le- } \\
\text { sions }\end{array}$ \\
\hline \multicolumn{4}{|c|}{ CT-guided percutaneous needle-mediated marking methods } \\
\hline Hook wire placement & $\begin{array}{l}\text { Leave a hook wire on the lung } \\
\text { surface preoperatively }\end{array}$ & $\begin{array}{l}\text { Easy and simple, good } \\
\text { amount of data }\end{array}$ & $\begin{array}{l}\text { High incidence of pneumothorax } \\
40 \% \text { ), possible dislodgement and loss of } \\
\text { the hook wire, multiple reports on poten- } \\
\text { tially fatal air embolism }\end{array}$ \\
\hline Dye marking & $\begin{array}{l}\text { Percutaneous dye injection be- } \\
\text { fore operation into the lung. Di- } \\
\text { rect visualization of marking } \\
\text { during operation }\end{array}$ & Easy and simple & $\begin{array}{l}\text { Concern about potential air embolism } \\
\text { due to percutaneous needle use }\end{array}$ \\
\hline Lipiodol marking & $\begin{array}{l}\text { Percutaneous injection of Lipi- } \\
\text { odol (enhancement). Fluoro- } \\
\text { scopic visualization during op- } \\
\text { eration }\end{array}$ & Easy and simple & $\begin{array}{l}\text { Concern about potential air embolism } \\
\text { due to percutaneous needle use. Room } \\
\text { setup necessary for fluoroscopy use dur- } \\
\text { ing operation }\end{array}$ \\
\hline \multicolumn{4}{|c|}{ Bronchoscopic marking methods } \\
\hline Barium marking & $\begin{array}{l}\text { Bronchoscopically inject bari- } \\
\text { um. Fluoroscopic visualization } \\
\text { during operation. Guided by } \\
\text { CT or virtual bronchoscopy }\end{array}$ & $\begin{array}{l}\text { Stays long. Good amount } \\
\text { of data with high success } \\
\text { ratio in tumor identifica- } \\
\text { tion. GGO. Complications } \\
\text { less concerning }\end{array}$ & $\begin{array}{l}\text { Room setup necessary for fluoroscopy } \\
\text { use during operation. Barium persists in } \\
\text { the lung if not resected. Excessive radia- } \\
\text { tion exposure to bronchoscopist if CT is } \\
\text { used }\end{array}$ \\
\hline Dye marking & $\begin{array}{l}\text { Bronchoscopically inject dye } \\
\text { (indigo carmine, indocyanine } \\
\text { green, etc.) guided by CT or } \\
\text { virtual bronchoscopy }\end{array}$ & $\begin{array}{l}\text { High success ratio. Compli- } \\
\text { cations less concerning }\end{array}$ & $\begin{array}{l}\text { Excessive radiation exposure to bron- } \\
\text { choscopist if guided by CT. Dye may } \\
\text { disappear relatively quickly }\end{array}$ \\
\hline Lipiodol marking & $\begin{array}{l}\text { Bronchoscopically inject Lipi- } \\
\text { odol using guide sheath and } \\
\text { virtual bronchoscopy }\end{array}$ & $\begin{array}{l}\text { Stays relatively long. Com- } \\
\text { plications less concerning }\end{array}$ & Intraoperative fluoroscopy necessary \\
\hline Coil marking & $\begin{array}{l}\text { Platinum coil is placed broncho- } \\
\text { scopically }\end{array}$ & $\begin{array}{l}\text { Stays long. Complications } \\
\text { less concerning }\end{array}$ & $\begin{array}{l}\text { Might displace. Coil persists in the lung } \\
\text { if not resected. Excessive radiation expo- } \\
\text { sure if guided by CT. Intraoperative flu- } \\
\text { oroscopy necessary }\end{array}$ \\
\hline
\end{tabular}

内圧の上昇が関与しているとの見方もある．頭部低位や 高圧酸素療法が有効との報告もあるが, 13,14 検索しうる 限り,この合併症を防ぐ有効な方法は報告されていない. 本法による術前マーキングの適応は慎重に行うべきと思 われる。

\section{2-2. その他の CT ガイド下肺穿刺マーキング法}

CTをガイドに, 経皮的に臓側胸膜に針を刺し, 色素 (インジゴカルミン, インドシアニングリーン, その 他) 15,16 や造影骫 (リピオドール), 17,18 マイクロコイル19 を注入する方法が報告されている．比較的簡便な方法で あり, hook wire と比べて出血しにくいとされるが, hook wire 法と同じく解剖学的な制限を受けること, より正確 に行うためにリアルタイムでの CT ガイド下マーキング を行うと術者被曝が増えることなどが久点として挙げら れる。

経皮的に肺の穿刺を行うため hook wire と同じく気 胸, 出血, 空気塞栓, 胸膜播種などの懸念がある. 検索 しうる限り空気塞栓の報告はなく, hook wireのように
針が留置されたままになるわけではないなど構造的によ り安全な可能性もあるが, 十分な症例集積がなされてい ない可能性もあり, やはり慎重な適応が求められる.

色素については, 術中特別な準備を必要とせずに視認 できることが利点だが, 時間経過とともに比較的速やか に拡散するといわれ，また色素が少し深い位置で注入さ れると術中確認できなくなることなどの欠点がある. 色 素一般の問題として, 炭粉沈着が強い症例では術中確認 が困難であるが，これについてはインドシアニングリー ンで蛍光胸腔鏡による可視化ができればある程度克服可 能かもしれない.

リピオドール, マイクロコイルは術中同定に透視が必 要であり, 手術のセットアップにはやや難がある。一方, 胸膜直下にマーキングされなければ術中確認がとれない 色素と比べ, リピオドール，マイクロコイルは透視を用 いさえすれば深い位置にマーキングされても確認可能 で, 病変よりも中枢のマーキングは, ある程度の深さの マージンを確保するのに役立つ可能性がある. 


\section{2-3. 胸腔穿刺を行わない経皮的 CT ガイド下マーキン グ}

従来の経皮的 CT ガイド下マーキングは, 空気塞栓な ど臓側胸膜穿刺に伴う重篤な合併症が眯念されるため, 臓側胸膜への穿刺を避ける目的で開発された方法であ る. 20 CT ガイド下マーキング時, 経皮的に血管内留置力 テーテルを病変部直近の壁側胸膜直上に進め, 外筒を留 置する．手術時，まず分離肺換気で留置しておいた外筒 から胸腔に中心静脈カテーテルを扱入し, 先端に小綿球 を装着後, 胸壁に牽引・固定する.両肺換気にしてカテー テルに色素（ピオクタニン）を注入, 小綿球を染色し, 肺表面にマーキング後肺部分切除を行う。本法開発の目 的ど抢り確かに臟側胸膜に針を刺さない安心感がある.

しかしこの方法は, 術前 CT に抢ける胸壁と腫瘍の位置 関係が, 術中両側換気した際のそれと同一であることが 前提となっている．肺表面へのマーキングは術中になさ れるため, マーキングされた部位が本当に腫瘍と一致し ているか確認のしょうがなく, 切除の確実性が担保され ない点が懸念される.

\section{3. 経気管支鏡的マーキング法}

術前マーキング法のうち, CT ガイド下の経皮的穿刺 法に対し，もう一つのカテゴリーが経気管支的（あるい は気管支鏡的）マーキングである。この方法の特徵は肺 に直接針を刺さないことによる安全性と，解剖学的な制 限が少なく, 肩甲骨裏面や肺尖，縦隔，横隔膜面，葉間 といった経皮的にアプローチ困難な部位にも到達可能で あることが特徴である. マーキングに用いられてきたの は色素, 21,22 バリウム, 23 リピオドール, 24 コイル 25,26 な どである。

標的となる気管支から正確にマーキングを行うため, CT ガイド下の気管支鏡が行われてきたが，これは CT 室に気管支鏡を持ち込む必要があり，かつ CT 室を比較 的長時間占拠する, 術者がかなり被曝する, 病変の位置 によりマーキング操作に難渋し検査施行に熟練を要す るなどの久点があった．最近は画像技術の発達に伴い バーチャル気管支鏡をガイドに用いるという報告が増え ており，27また endobronchial ultrasound-guide sheath (EBUS-GS) 法による腫瘍生検法が確立，普及するととも に，バーチャル気管支鏡とこのテクニックを併用して， 経気管支的に目的の部位に注入する方法が報告されてい る. 24

色素は術中直接視認可能なため手術自体に特別な準備 が不要なのが利点だが，肺表面にマーキングがなされて いなければ確認できず，また比較的速やかに色素が拡散 するといわれている，バリウム，造影剤，コイルは術中 確認に透視が必要となる一方，色素のようにマーキング
が胸膜直下である必要は必ずしもない．またマーカーが 比較的長期または半永久的に残存することは手術に向け ては利点だが，手術で切除されなかった場合に異物とし て肺内に長期残存することがどのような影響を及ぼすの かが問題となりうる.

コイルによる方法は，比較的中枢の気道（肺切除とい う視点では胸膜から離れた深い位置）に安定してマー カーを留置でき，したがって梁さのマージンをある程度 得ることができる点は大きな利点となりうると思われ る.

\section{VAL-MAP : マーキングからマッピングへ}

最近われわれは，従来のマーキング法の問題点を克服 し, 安全かつ確実な手術を行うための新たな方法, VAL-

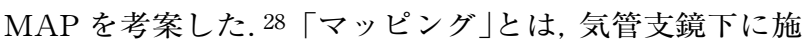
す複数個のマーキングが与える肺表面の「座標」によっ て, 病変の同定のみならず十分なマージンを確保した高 精度の呼吸器外科手術を実現するための新たな方法であ る. 本法を支えるのは thin-slice CT とそれに基づく $3 \mathrm{D}$ 画像技術であり，これらが広く行きわたった本邦におい ては，VAL-MAP を施行するために特別な施設や道具を 必要としない。京都大学では 2014 年 5 月現在, VALMAP を用いて既に約 120 症例 180 箇所の病変に対して 約 400 䉂所のマーキングが実施され，合併症は治療不要 の軽微な気胸を 5 例に認めたのみである. $99 \%$ を越える 確実性の高い切除が可能となっている.

\section{4-1. VAL-MAP の特徵}

VAL-MAP は, 経気管支的肺マーキングの変法ともい えるが, 複数の点で従来のマーキング法と異なっている (Table 2). まずマッピングの目的は, 病変の位置同定だ けでなく，十分なマージンを確保した切離ラインを設定 することであり，このために複数個のマーキングが同時 に施される。マーキング部位は前述の経皮的アプローチ では肩甲骨裏面, 横隔膜面, 肺尖, 縦隔面, 葉間などが アクセス不能な部位であり，経気管支的アプローチでは アクセス部位は気管支の解剖に規定されていた(つまり, 気管支の至らない部分にはアクセスできない)，VALMAPも後者の制限があるが，ここに解剖学的ランド マークと補助線 (auxiliary line) をマップの一部として利 用することで，事実上肺表面のあらゆる部分をカバーす るマッピング，術中ナビゲーションが可能となった. 29 確実性の点でも，複数マーキングが互いに補完しあうた め, 1 箇所のマーキングがうまくいかなくても全体とし てのマッピングは失敗することが少ない．またマーキン グ位置がずれても，後述のようにマッピング後にCT を 撮影するため，この時点でマップの修正が可能である. 
Intraoperative Localization of Small Lung Cancer-Sato

Table 2. Comparison of Conventional Marking Techniques and Virtual-assisted Lung Mapping (VAL-MAP)

\begin{tabular}{|c|c|c|}
\hline & Conventional marking techniques & VAL-MAP \\
\hline Purpose & Localization of a target lesion & $\begin{array}{l}\text { Determination of appropriate resection lines with safe } \\
\text { surgical margin }\end{array}$ \\
\hline Application & Usually wedge resection & $\begin{array}{l}\text { Wedge resection, segmentectomy (esp. complex, extend- } \\
\text { ed segmentectomy) }\end{array}$ \\
\hline Anatomical limitation & $\begin{array}{l}\text { Both percutaneous and transbronchial } \\
\text { methods have inaccessible areas }\end{array}$ & $\begin{array}{l}\text { Anatomical limitation of transbronchial approach is } \\
\text { mostly overcome by combining anatomical landmarks } \\
\text { and/or auxiliary lines as parts of the lung map }\end{array}$ \\
\hline Number of marking spots/tumor & Usually one & $\begin{array}{l}\text { Multiple (2-3 for wedge resection, } 3-6 \text { for segmentecto- } \\
\text { my) }\end{array}$ \\
\hline Estimation of tumor localization & Estimated based on one marking & $\begin{array}{l}\text { Estimated based on relative location of multiple mark- } \\
\text { ings }\end{array}$ \\
\hline $\begin{array}{l}\text { Outcome of marking failure (e.g. } \\
\text { dislodgement of hook wire, dis- } \\
\text { appearance of dye marking) }\end{array}$ & $\begin{array}{l}\text { Planned resection becomes extremely } \\
\text { difficult or impossible }\end{array}$ & $\begin{array}{l}\text { Still possible because multiple markings complement } \\
\text { with each other }\end{array}$ \\
\hline Outcome of displaced marking & $\begin{array}{l}\text { Planned resection becomes extremely } \\
\text { difficult or impossible }\end{array}$ & $\begin{array}{l}\text { Still possible because actual marking localization is con- } \\
\text { firmed by post-mapping CT, based on which 3D images } \\
\text { are reconstructed preoperatively. Operation plan (i.e. } \\
\text { planned resection lines) is adjusted before operation }\end{array}$ \\
\hline
\end{tabular}

\section{4-2. VAL-MAP の手順}

VAL-MAP の手順を Figure 1A に示す. (1)最大 6〜7 箇所程度までのマーキング部位を, 手術計画に応じてデ ザインする. 部分切除であれば $2 \sim 3$ 箇所, 区域切除なら 4〜6 箇所程度が使われることが多い. (2)バーチャル気管 支鏡を用いて目標気管支を決定する. Synapse Vincent (富士フイルムメディカル), BF-NAVI (オリンパス), LungPoint (Broncus) などのバーチャル気管支鏡ソフト は, 目標部位に到達する経路をある程度自動選択してく れるため便利だが, フリーソフトウエアや通常の 3D ワークステーションでもマニュアル操作で同様のことが 可能である. 第 6〜11 分枝程度まで同定しておく. (3)実 際のマッピングは，通常の内視鏡室の透視下に，術前 2 日以内に行う。通常の気管支鏡検査と同じく局所麻酔下 に軽い鎮静（ミダゾラム $2 \sim 3 \mathrm{mg}$ 静注など）を用いて気 管支鏡を挿入する．使用する気管支鏡は $2 \mathrm{~mm}$ 径のチャ ンネルが必要で, BF-260または BF-P260F (オリンパス) が用いられることが多い. 気管支内噴霧用カテーテル PW-6C-1 (オリンパス) は先端が金属であり，これに $1 \mathrm{ml}$ のインジゴカルミンを事前にローディングしておく．目 標気管支を同定したらカテーテルを進め, 透視でカテー テルの進行方向を確認したうえでさらにカテーテルを進 める. 先端が胸膜直下に到達していることを透視で確認 する．ただし葉間や横隔膜面では確認できないので，カ テーテルの動きから判断する. 胸膜直下ではカテーテル が wedge しているので, シリンジを押すことはできな い.ここでシリンジを押した状態で透視を見ながら $\mathrm{mm}$ 単位でゆっくりカテーテルを引き抜き, 先端が unwedge してシリンジが押せるようになる瞬間を逃さずにわずか にカテーテルを進める. インジゴカルミン $1 \mathrm{ml}$ に続いて
エア $20 \mathrm{ml}$ を注入し, 胸膜にインジゴカルミンを吹き付 ける.この操作を各マーキングに対して行う。これまで の各施設のデータから, 所要時間はマーキング 1 箇所当 たり約 3 分である. (4)マッピングに続いて胸部単純 CT を撮影する、マッピング部位は通常, 気管支拡張を伴う GGO として認識可能である (Figure 1B). マッピング終 了から 2 時間以内の撮影が望ましい. というのも, イン ジゴカルミン自体は放射線透過性があるが, 肺内に吹き 付けられたインジゴカルミンはしばらくの間, その水の 成分が CTに写る.これは気管支肺胞洗浄後の CT の アーチファクトと同じ原理である。また空気の注入によ る気管支拡張像も確認される. (5)マッピング後の CTを 用いて, 実際に施されたマーキングと病変の位置関係を 3D に再構成する (Figure 1C). ここで仮に各マーキング が予定されていた位置とずれていたとしても, 実際の マーキングをもとに「マップ」が構成されるので, これ に従った手術計画に修正が可能である. (6)手術を行う. 術野はマッピング後 $3 \mathrm{D}$ とほとんど同じょうに見えるの で (Figure 1D), これに従って肺切除（部分切除や区域 切除)を行う．2 日前に施されたマッピングでも，インジ ゴカルミンが臓側胸膜に直接噴き付けられているため良 く見える.

\section{4-3. VAL-MAP の適応}

VAL-MAP はこれまでの「触知困難な病変の同定」と いうマーキングの概念を越え, 切離ラインの設定と, 肺 という術中形が大きく変わる特殊な蔵器の術中ナビゲー ションとしての役割が大きい. したがって, VAL-MAP の適応は触知困難病変に留まらず, 切除ライン設定に不 安のある様々な状況が考えられる.

ここで特筆すべきは区域切除の切離線設定で, 特に拡 

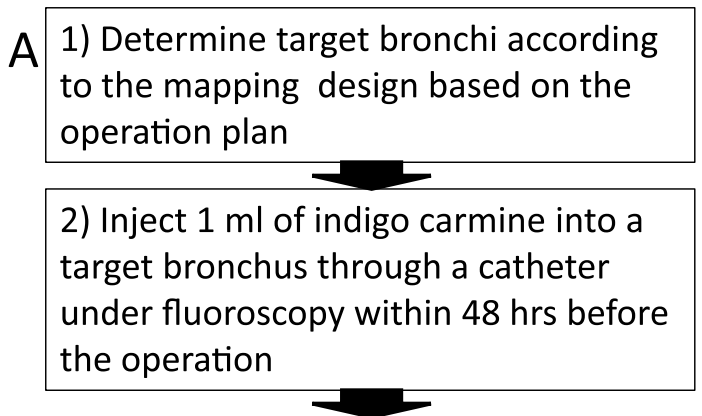

3) Take post-mapping CT scan (B)
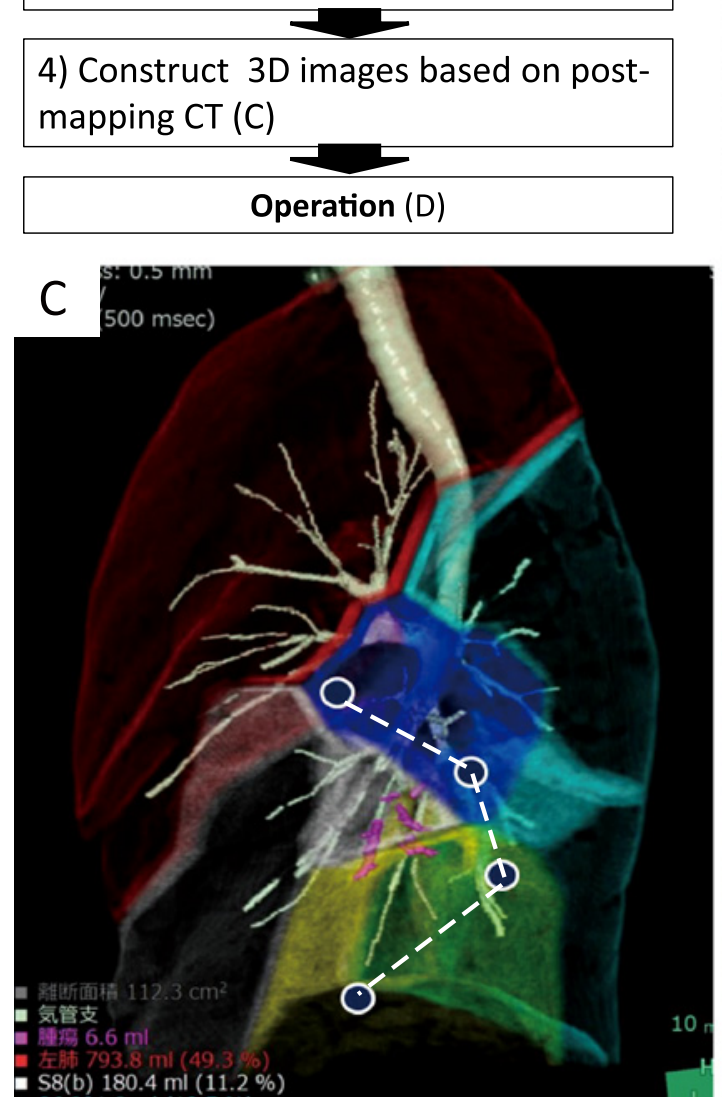

Figure 1. Virtual-assisted lung mapping (VAL-MAP). (A) Steps in VAL-MAP. (B) A post-VAL-MAP CT scan showing a marking (arrow) posterior to the tumor (arrowhead). Note that the markings made by VAL-MAP are typically displayed as areas of ground glass opacity with mild bronchiectasis on CT scans. (C) A 3D image constructed from a post-VAL-MAP CT scan. The arrow indicates the tumor location. Each marking spot is indicated by a circle. The interrupted line indicates the imaginary resection line for extended segmentectomy $\left(\mathrm{S}^{8}+\mathrm{S}^{9} \mathrm{~b}+\mathrm{a}\right.$ part of $\left.\mathrm{S}^{10}\right)$. (D) Intraoperative view after VAL-MAP. The arrows indicate multiple markings made by the VAL-MAP device (same case as in B and $\mathbf{C}$ ).
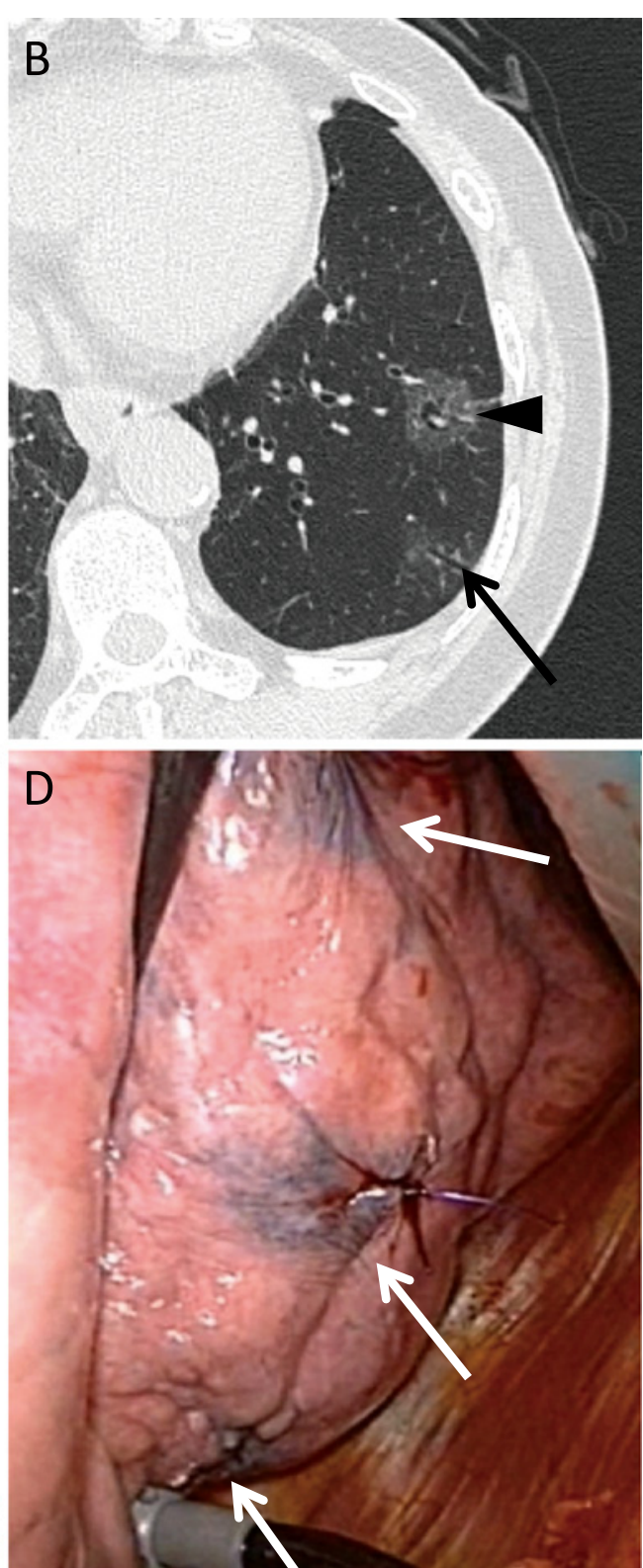

大区域切除, 亜区域合併切除といった従来の解剖学的区 域にとらわれない切除への応用である.そもそも腫瘍は, 区域切除が発達したルーツである抗酸菌症と違って区域 に沿ってできる病気ではないので, 解剖学的区域にとら われて不十分なマージンに終わる切除はナンセンスであ る. 本法の特徴は, 肺門の脈管処理による安全性と肺門 
後, マッピングに向かって未梢肺を切除することで対処 可能である.

\section{4-4. VAL-MAP多施設共同研究 - Multi-Institutional Lung Mapping (MIL-MAP) Study}

特別な器具が不要で, 基本的にどこの施設でも実施可 能なことをコンセプトに開発したVAL-MAP 法は, 有効 性と安全性を検証するための多施設共同研究としての臨 床試験が, 現在進行中である. 2013 年 10 月に開始となっ た本試験では, 2014 年 5 月現在, VAL-MAP を既に実施 しているのが 11 施設, 準備中が 12 施設あり, 京都大学 外で既に約 60 例の VAL-MAP が安全に施行されてい る. 参加施設は 2014 年 5 月現在継続して募集中であり, 技術的なサポート, 参加施設間の情報共有など, 多角的 な活動を行っている.

\section{4-5. VAL-MAP の課題}

VAL-MAP はこれまで良好な切除成績と安全性を示 しているが, 課題もある。まず現在の方法では深部マー ジンは十分な保証ができない. 部分切除では外側のマー ジンを多めにとるようなマーキングを施すことで対応し てきたが,さらに正確な深部マージンを確保する手法の 開発が急がれる。また, マーキング困難症例（気腫や炭 粉沈着の強い症例）への対策も講じる必要がある. 最後 に，本法は手技的には比較的シンプルではあるものの， その準備には多少手間がかかるところがあり，より簡便 に実施するためのシステムを追求することで，さらに本 法が普及し，より多くの患者さんの治療に貢献できるも のと考える.

\section{結 語}

小型肺癌をはじめとする微小腫瘍性肺病変の術中局在 同定法について，報告されている術前マーキング法を中 心に概説した。 それぞれの方法に一長一短があるが，最 も重視されるべきは当然のことながら，患者の安全性と 切除の確実性である.われわれが開発したVAL-MAP は気管支鏡下術前マーキングの利点を最大限活かし，従 来の局在同定を目的としたマーキングを，手術ナビゲー ションとしての「マッピング」へと進化させたものであ る、VAL-MAP を含め, この分野のさらなる発展と臨床 への還元が期待される.

本論文内容に関連する著者の利益相反：なし

\section{REFERENCES}

1. Dendo S, Kanazawa S, Ando A, Hyodo T, Kouno Y, Yasui K, et al. Preoperative localization of small pulmonary lesions with a short hook wire and suture system: experience with 168 procedures. Radiology. 2002;225:511518.
2. Sortini D, Feo C, Maravegias K, Carcoforo P, Pozza E, Liboni A, et al. Intrathoracoscopic localization techniques. Review of literature. Surg Endosc. 2006;20:13411347.

3. Horan TA, Pinheiro PM, Araújo LM, Santiago FF, Rodrigues MR. Massive gas embolism during pulmonary nodule hook wire localization. Ann Thorac Surg. 2002;73: 1647-1649.

4. Iguchi T, Yoshioka T, Muro M, Miyasho K, Inoue D, Hiraki T, et al. Systemic air embolism during preoperative pulmonary marking with a short hook wire and suture system under CT fluoroscopy guidance. Jpn J Radiol. 2009;27:385-388.

5. Sakiyama S, Kondo K, Matsuoka H, Yoshida M, Miyoshi T, Yoshida S, et al. Fatal air embolism during computed tomography-guided pulmonary marking with a hooktype marker. J Thorac Cardiovasc Surg. 2003;126:1207-1209.

6. 松浦陽介, 渡 正伸. CT ガイド下肺穿刺後に心腔内空気 栓を生じた 2 症例. 日本呼吸器外科学会雑誌. 2010;24: 967-971.

7. Endo M, Kotani Y, Satouchi M, Takada Y, Sakamoto T, Tsubota N, et al. CT fluoroscopy-guided bronchoscopic dye marking for resection of small peripheral pulmonary nodules. Chest. 2004;125:1747-1752.

8. Khereba M, Ferraro P, Duranceau A, Martin J, Goudie E, Thiffault $\mathrm{V}$, et al. Thoracoscopic localization of intraparenchymal pulmonary nodules using direct intracavitary thoracoscopic ultrasonography prevents conversion of VATS procedures to thoracotomy in selected patients. J Thorac Cardiovasc Surg. 2012;144:1160-1165.

9. Mattioli S, D’Ovidio F, Daddi N, Ferruzzi L, Pilotti V, Ruffato A, et al. Transthoracic endosonography for the intraoperative localization of lung nodules. Ann Thorac Surg. 2005;79:443-449.

10. Nomori H, Horio H. Endofinger for tactile localization of pulmonary nodules during thoracoscopic resection. Thorac Cardiovasc Surg. 1996;44:50-53.

11. Kanazawa S, Ando A, Yasui K, Mitani M, Hiraki Y, Shimizu N, et al. Localization of pulmonary nodules for thoracoscopic resection: experience with a system using a short hookwire and suture. AJR Am J Roentgenol. 1998; 170:332-334.

12. 近藤 健, 徳永義昌, 齊藤正男, 中川達雄. CT ガイド下 マーキングによる空気塞栓の 2 例. 日本呼吸器外科学会 雑誌. 2012;26:729-733.

13. 水谷栄基, 中原和樹, 宮永茂樹, 吉屋智晴. CT ガイド下 マーキングによる空気塞栓症に対する高圧酸素療法. 胸 部外科. 2012;65:899-902.

14. 黒田慎太郎, 江藤高陽, 角舎学行, 小出 圭, 先本秀人, 高橋 信. 肺腫瘤に対するCT ガイド下マーキング中に 発症した空気塞栓症の 1 例. 日本臨床外科学会雑誌. 2005;66:1291-1294.

15. 茅野修二, 栗山啓子, 礒橋佳也子, 村田昌之, 三谷 尚, 津田＼cjkstart恭, 他. 色素注入による肺腫瘍術前 CT 下マーキン グ. 日本医学放射線学会雑誌. 2003;63:308-310.

16. 宮原栄治, 津谷康大, 鈴木崇久, 南一仁, 龟田 彰, 野 宗義博．末梢性肺腫瘤性病変に対する胸脉鏡下手術 塩 酸リドカインゼリーを併用した色素法による術前マーキ ング. 日本内視鏡外科学会䧱誌. 2007;12:547-553. 
17. Nomori H, Horio H, Naruke T, Suemasu K. Fluoroscopyassisted thoracoscopic resection of lung nodules marked with lipiodol. Ann Thorac Surg. 2002;74:170-173.

18. Ikeda K, Nomori H, Mori T, Kobayashi H, Iwatani K, Yoshimoto K, et al. Impalpable pulmonary nodules with ground-glass opacity: Success for making pathologic sections with preoperative marking by lipiodol. Chest. 2007; 131:502-506.

19. Lizza N, Eucher P, Haxhe JP, De Wispelaere JF, Johnson PM, Delaunois L. Thoracoscopic resection of pulmonary nodules after computed tomographic-guided coil labeling. Ann Thorac Surg. 2001;71:986-988.

20. 増田大介, 西田 達, 秋月克彦, 丁 奎光, 藤井祥貴, 岩 崎正之. 未梢小型肺病変に対する胸腔穿刺を行わない経 皮的 CT ガイド下マーキング. 日本呼吸器外科学会雑誌. 2011;25:604-610.

21. Krimsky WS, Minnich DJ, Cattaneo SM, Sarkar SA, Harley DP, Finley DJ, et al. Thoracoscopic detection of occult indeterminate pulmonary nodules using bronchoscopic pleural dye marking. J Community Hosp Intern Med Perspect. 2014;4. doi: 10.3402/jchimp.v4.23084.

22. Sakamoto T, Takada Y, Endoh M, Matsuoka H, Tsubota $\mathrm{N}$. Bronchoscopic dye injection for localization of small pulmonary nodules in thoracoscopic surgery. Ann Thorac Surg. 2001;72:296-297.

23. 山田崇央, 小山泰規, 升井朝美, 田宮暢代, 細木誠之, 平 松 真, 他. 肺小型病変に対する気管支鏡下バリウムマー キングの有効性と安全性の検討. 気管支学. 2009;31:6267.
24. 深澤基児, 三沢昌史，阿部 大，武士昭彦. 術中同定困難 な肺末梢小型 ground-glass opacities (GGO) に対する EBUS-GS および気管支ナビゲーションシステムを用い たマーキング法. 気管支学. 2014;36:7-11.

25. Miyoshi T, Kondo K, Takizawa H, Kenzaki K, Fujino H, Sakiyama S, et al. Fluoroscopy-assisted thoracoscopic resection of pulmonary nodules after computed tomography--guided bronchoscopic metallic coil marking. J Thorac Cardiovasc Surg. 2006;131:704-710.

26. Toba H, Kondo K, Miyoshi T, Kajiura K, Yoshida M, Kawakami Y, et al. Fluoroscopy-assisted thoracoscopic resection after computed tomography-guided bronchoscopic metallic coil marking for small peripheral pulmonary lesions. Eur J Cardiothorac Surg. 2013;44:e126-e132.

27. Asano F, Shindoh J, Shigemitsu K, Miya K, Abe T, Horiba $\mathrm{M}$, et al. Ultrathin bronchoscopic barium marking with virtual bronchoscopic navigation for fluoroscopyassisted thoracoscopic surgery. Chest. 2004;126:1687-1693.

28. Sato M, Omasa M, Chen F, Sato T, Sonobe M, Bando T, et al. Use of virtual assisted lung mapping (VAL-MAP), a bronchoscopic multispot dye-marking technique using virtual images, for precise navigation of thoracoscopic sublobar lung resection. J Thorac Cardiovasc Surg. 2014; 147:1813-1819.

29. Sato M, Aoyama A, Yamada T, Menjyu T, Chen F, Sato $\mathrm{T}$, et al. Thoracoscopic wedge lung resection using virtual-assisted lung mapping. Asian Cardiovasc Thorac Ann. 2014 [Epub ahead of print] doi: 10.1177/ 0218492314539332 